\title{
Does e-HRM Improve Labour Productivity? A Study of Commercial Bank Workplaces in
}

\section{Pakistan}

Authors' Pre-publication version to appear in Iqbal, N., Ahmad, M., Allen, M.M.C. and Raziq, M.M. (2018) Employee Relations, 40(2).

\begin{abstract}
Purpose: Drawing on data from a unique, large-scale survey, we examine the links between eHRM and perceived labour productivity both directly and through the mediating role of HR service quality amongst commercial-bank workplaces in Pakistan, many of which have introduced e-HRM.
\end{abstract}

Design: We use partial least squares structural equation modelling to examine the direct links between e-HRM and productivity as well as the mediated links between e-HRM, perceived HR service quality and productivity.

Findings: We show that e-HRM practices have a statistically significant, positive effect on managers' perceptions of labour productivity. We also reveal that e-HRM practices influence the quality of HR service, and that the quality of HR services fully mediates the relationship between e-HRM practices and managers' perceptions of labour productivity.

Practical implications: Our results highlight the importance of designing and implementing eHRM systems so that they support organization workflow and enable workers to carry out a range of HR and non-HR activities more efficiently. In particular, this study suggests that 
managers should focus on how e-HRM impacts on HR service quality in a holistic way, as this is the 'route' via which e-HRM can improve labour productivity.

Originality: Existing research has demonstrated a link between e-HRM and the quality of HR services; however, these studies downplay the potential impact of e-HRM on labour productivity, a key organizational outcome and one that e-HRM aims to improve. The study contributes to the HRM literature by identifying how e-HRM can improve labour productivity by enhancing the perceived HR service quality. The study, therefore, provides the basis for future theory developments in this area.

Keywords: Human resource management; labour utilization; Line managers; Organizational performance; e-HRM; structural equation modelling 


\section{Introduction}

Existing studies have revealed an important association between e-HRM and the quality of HR services (Bondarouk et al., 2017; Wahyudi and Park, 2014); however, research on the links between e-HRM and strategic objectives is limited (Marler and Fisher, 2013; Parry, 2011; Parry and Strohmeier, 2014; Schalk et al., 2013; Stone \& Dulebohn, 2013; Strohmeier, 2007). For instance, previous studies have not examined the direct and indirect links between e-HRM and labour productivity (Marler and Fisher, 2013; Obeidat, 2016; Strohmeier, 2007). Productivity is arguably an even more important outcome for many organizations than the quality of HR services, as improving workforce efficiency can enhance firms' competitiveness (Aryee, Walumbwa, Seidu, Otaye, 2013; Datta et al., 2005; Delery \& Shaw, 2001), and companies often introduce e-HRM to enable HR and other employees to focus to an even greater extent on key value-adding activities.

We respond to calls to extend work e-HRM, and focus on e-HRM's direct impact on labour productivity (Marler and Fisher, 2013; Obeidat, 2016) as well as its indirect effect on productivity that is mediated by employers' perception of the quality of HRM services on productivity (Uen, Ahlstrom, Chen \& Tseng, 2012; Zheng \& Lamond, 2010). If e-HRM does enable employees to perform HR-related activities more conveniently, they are likely to perceive the quality of HR services as high and should have more time for other activities. Existing research has not addressed these relationships (Marler and Fisher, 2013; Obeidat, 2016; Stone \& Dulebohn, 2013; Strohmeier, 2007). In addition, research on e-HRM has mostly been conducted in the context of developed European and US economies, and has paid little attention to different national contexts (Bondarouk, Schilling, \& Ruël, 2016) 
We focus on commercial banks in Pakistan for four reasons. First, this sector is one of the most profitable sectors of the economy (Khan, 2009), facilitating the use of the latest management trends and technology. Second, it is expected to remain a strong contributor to the economy (KPMG, 2013), making it an important formal sector within Pakistan's largely informal economy (Ahmad and Allen, 2015). Third, banks' use of individual e-HRM practices and systems has risen sharply recently, as top management has focused on the quality of HR processes and productivity to improve competitiveness (Sabir, Abrar, Bashir, Baig, \& Kamran, 2015), enabling us to assess the links between e-HRM and labour productivity. Finally, very little is known about the use of different HRM policies, including e-HRM, and their impact on organizational outcomes in Pakistan (Khilji, 2001). In high power-distance cultures, such as Pakistan (Ahmad and Allen, 2015), some employees may think that performing HR tasks themselves as 'beneath them', potentially limiting their satisfaction with e-HRM and any impact of e-HRM on productivity (Johnson et al., 2016). Studying e-HRM in Pakistan could, therefore, highlight how cultural norms influence how HR practices impact on organizational outcomes.

We, therefore, seek to make three contributions to the literature. First, we enlarge the focus of research on e-HRM's impact on organizational outcomes. Despite the growing importance of eHRM, existing research has tended to examine the effects of e-HRM on the productivity of the HRM function (CedarCrestone, 2008,2013; Marler and Parry, 2015; Obeidat, 2016; Stone and Dulebohn, 2013). Whilst this is undoubtedly important, we draw on existing empirical evidence that highlights a potential link between e-HRM and overall workplace productivity. Second, by adopting an exploratory approach, we seek to make a contribution to theory building in an 
emerging area of HRM research. Finally, we respond to recent calls to extend HRM research to emerging economies to explain better how particular HRM policies affect organizational outcomes in different institutional and cultural contexts (Budhwar and Debra, 2009; OlivasLujan et al., 2007).

\section{Definition of e-HRM}

Definitions of e-HRM abound (Johnson, Lukaszewski and Stone, 2016). Generally, e-HRM is an organization strategy to help align employee behaviour with strategic choices by using flexible and integrated technologies (Marler and Fisher, 2013; Marler, 2009; Panos \& Bellou, 2016). More specifically, Johnson et al. (2016, p. 29) define e-HRM as 'the implementation and delivery of HR functionality enabled by a HRIS [HR information system] that connects employees, applicants, managers, and the decisions they make.' This definition conceives of eHRM as a platform that internal and external stakeholders use to access HRM processes and functions, and that the wider HR information system enables (Johnson et al., 2016). As Bondarouk and Ruël (2009: p 507) note e-HRM also has a strategic purpose as it aims to create 'value within and across organizations for targeted employees and management.' In other words, e-HRM is not just an IT tool to perform HRM activities; it is a means to integrate various HRM and IT activities within organizations to attempt to improve employees' working conditions and the performance of the organization as a whole (Bondarouk and Ruel; 2013; Johnson et al. 2016; Lengnick-Hall and Moritz, 2003; Obeidat, 2016; Panos \& Bellou, 2016). 


\section{Literature Review}

The existing research on e-HRM has adopted numerous theoretical perspectives and analytical foci (Marler and Fisher, 2013), including the resource-based view of the firm (Parry, 2011), dynamic capability theory (Bondarouk and Ruel, 2013), contingency theory (Marler and Parry, 2015), theories of how innovations diffuse (Bondarouk, Schilling and Ruel, 2016), adaptive structuration theory (Bondarouk et al., 2017) and social exchange theory (Bissola \& Imperatori, 2014). We adopt an exploratory approach that draws on insights from information systems (IS) research. In particular, we focus on the links between e-HRM, labour productivity, and service quality. The latter concept is also an important issue within the IS literature, a key strand of which has focused on service quality as a measure of IS success (DeLone and McLean, 2003; Pitt et al., 1995).

The IS literature operationalizes service quality by examining how far the service provided by the IS matches employee expectations (Tam and Oliveira, 2016). As HRM departments provide services through HRIS-enabled e-HRM to internal and external 'customers' (current and potential employees), we argue that drawing on the concept of service quality to measure the effectiveness of e-HRM is appropriate. Existing research has found a positive and significant link between e-HRM and HR service quality (Bondarouk et al., 2017; Wahyudi \& Park, 2014).

Importantly, the broader IS literature has assessed whether or not the use of IS leads to productivity gains for firms, and has often found either no increase in how efficiently employees work (Brynjolsson, 1993; Brynjofsson and Hitt, 2000; Jain and Kanungo, 2005) or only a very small increase (Polák, 2017), leading to a 'productivity paradox' (Brynjolsson, 1993). Thus, the 
impact of IS, generally, on labour productivity is marginal at best. In such a situation, the possibility that other factors mediate the relationship between IS and individual productivity cannot be ignored (Jain and Kanungo, 2005).

We draw on these findings to assess whether e-HRM service quality mediates between e-HRM and labour productivity. Although a practitioner survey has highlighted a positive association between e-HRM and labour productivity (CedarCrestone, 2008, 2013), the relationship between e-HRM and workplace labour productivity is under researched and there is a need to examine this link to promote theory building (Marler and Fisher, 2013; Obeidat, 2016), as there is little agreement on how e-HRM influences organizational performance (Bondarouk and Ruel, 2014; Marler and Fisher, 2016; Obeidat, 2016) and positive effects of e-HRM on organizational performance are not guaranteed (Bondarouk, Schilling, \& Ruël, 2016). However, a system that promotes errorless administration or enables employees to complete tasks quicker (i.e improves HR service quality) (Bondarouk et al., 2017; Wahyudi \& Park, 2014) is likely to help firms to improve labour productivity (CedarCrestone, 2006).

In short, existing studies have revealed a positive and significant link between e-HRM and HR service quality (Bondarouk et al., 2017; Strohmeier and Kabst, 2014; Wahyudi \& Park, 2014). Other work has indicated that HR service quality improves the productivity of the HRM function (Bissola and Imperatori, 2013; Ruel and Kaap, 2012). In addition, e-HRM can enable the organization to improve labour productivity by performing HR activities quicker than traditional practices and enabling non-HR employees to focus on core duties (CedarCrestone, 2006, 2013; Marler and Parry, 2015; Parry, 2011; Parry and Tyson, 2011; Strohmeier, 2007). However, the 
lack of theory in this area means that there is a need to carry out empirical research that can integrate these findings within a holistic model to capture the direct and indirect effects of eHRM on labour productivity (Marler \& Fisher, 2013; Strohmeier, 2007).

This study contributes to theory building by exploring the direct relationship between e-HRM and labour productivity as well as the possibility that HR service quality mediates this relationship. For instance, the link between e-HRM and labour productivity may be fully mediated by employers' perceptions of the quality of the HR service. This may indicate that it is not e-HRM practices in themselves that matter, but their ability to improve the quality of the HRM service, as they enable employees to perform their duties quicker and provide them with more accurate strategic and operational HR information when they need it (CedarCrestone, 2013; Parry and Tyson, 2011; Strohmeier, 2007).

\section{Hypothesis Development}

\section{E-HRM and perceived labour productivity}

Organizations differ in their use of e-HRM. First, the breadth of e-HRM refers to the number of e-HRM practices that an organization uses (Parry, 2011). Second, the depth of e-HRM indicates the degree to which each e-HRM practice is embedded (Bissola and Imperatori, 2013). Using the variation in the extent to which bank branches use different e-HRM practices, we explore the links between e-HRM and labour productivity.

Labour productivity is a key outcome and refers to how efficiently a firm's labour force works

(Datta, Guthrie, \& Wright, 2005; Paauwe, 2009). E-HRM systems create unique opportunities 
for employees to enhance their capabilities and thus contribute to the organization's success (Panos \& Bellou, 2016; Marler and Fisher, 2013; Bissola and Imperatori, 2013; Bonaruk and Ruel, 2013). The practices associated with e-HRM can provide an efficient and alternative way to perform HR processes more accurately and efficiently, potentially leading to greater labour productivity (Marler and Parry, 2015; Parry, 2011; Lengnick-Hall and Moritz 2003; Shrivastava \& Shaw, 2003; Snell, Stueber, \& Lepak, 2002).

The basic goal for e-HRM as an employment system is to improve employee productivity rather than simply using technology for HRM processes. Some existing work suggests that e-HRM value creation depends on the extent to which e-HRM practices are used: organizations with more e-HRM practices outperform those organizations with fewer e-HRM practices (Cedarcrestone, 2009). Drawing on existing empirical evidence, we argue that the more e-HRM practices a workplace uses, the more likely that establishment is to experience productivity gains (Bissola and Imperatori, 2013; Cedarcrestone, 2009; Parry, 2011; Panos \& Bellou, 2016) and hypothesize that e-HRM has a direct and positive impact on managers' perceptions of labour productivity.

We focus on perceived labour productivity for two reasons. First, IT-related productivity changes are difficult to capture using economic measures, as such measures may cover a diverse range of organizational activities and IT uses (Brynjolfsson, 1993; Brynjolfsson and Hitt, 2000). Second, productivity is a multi-dimensional construct that is difficult to assess using one quantitative statistic, such as task performance (DeLone and McLean, 2003). Therefore, as we detail below, 
we ask managers within the bank branches to assess how e-HRM has influenced a broad range of employee activities, and hypothesize that:

H1: In workplaces that adopt more e-HRM practices, managers will assess labour productivity to be higher.

\section{E-HRM and the Quality of HR Services}

Value has been defined in terms of efficiency and HR service quality (Marler and Fisher, 2016; Ruël \& Kaap, 2012; Wahyudi \& Park, 2014). HR service quality has been shown to be an important value-creating factor for employees. One of the reasons why firms use e-HRM is to improve the quality of their HR services to employees (Bondarouk et al., 2017; Wahyudi \& Park, 2014; Tyson and Parry, 2011). HR service quality refers to the 'expectations of an increase in HRM service quality through the implementation of e-HRM' (Bondarouk et al. (2017, p. 4). By improving the quality of the services that HR provides to employees, firms may be able to enhance their productivity (Marler and Parry, 2016; Uen et al., 2012).

Most recent e-HRM studies propose large increases in the quality of HRM services through eHRM (Bondarouk et al., 2017; Ruel et al., 2007; Ruel and Bondarouk, 2014; Ruel and Kaap, 2012; Wahyudi and Park, 2014), which increases in managers' perception of the HR service will reflect. Empirical evidence supports these arguments; for example, Wahyudi \& Park (2014) found that the scope of e-HRM practices is a strong predictor of HR service quality. Bondarouk 
et al.'s (2017) and Wahyudi and Park's (2014) results indicate that e-HRM is positively associated with HR service quality. We, therefore, propose:

$\mathrm{H} 2:$ The greater the use of e-HRM practices, the higher the perceived HRM service quality will be.

\section{HR service quality and labour productivity}

Firms have recognized the importance of improving the quality of HR services that they provide and focus on productivity to enhance their sustainable competitive advantage (Paauwe, 2009). The perceived quality of HR services can increase employee satisfaction and, as a result, enhance how managers perceive employee productivity (Aryee et al., 2013; Bondarouk et al., 2017; Chang, 2005; Uen et al., 2012).

Reliable HR services can improve the interaction between those with HR responsibilities, including line managers, and employees, leading to increases in perceived HR service quality (Bissola \& Imperatori, 2013; Uen et al., 2012). By improving the HR service, employers can seek to improve employees' productivity (Drucker, 1999; Meijerink et al., 2016; Uen et al., 2012). However, studies that examine the relationship between HR service quality and organizational outcomes, such as labour productivity, are limited (Marler and Parry, 2011; Parasuraman, 2010). Aryee et al (2013) have argued that service quality is not the ultimate performance outcome for organizations, and future studies should examine the relationship between perceived HR service quality and performance outcomes, such as labour productivity. We, therefore, hypothesize: 
H3: The higher the perceived HRM service quality is, the higher manager's perceptions of labour productivity will be.

\section{The mediating role of HRM service quality}

Previous research suggests that e-HRM systems can improve the quality of HR processes and eventually influence strategic outcomes (Bondarouk and Ruel, 2013; Meijerink, Bondarouk \& Lepak, 2015; Parry and Tyson, 2011). Consequently, the quality of HR services has a central position in the e-HRM performance causal chain. Uen (2012) has argued that HR service quality should be evaluated through an input, process and output quality framework. The output of $H R$ service quality describes the consequences of service quality and demonstrates what an organization is achieving by providing quality services to employees. If $\mathrm{HR}$ services meet employees' needs, their productivity is likely to increase (Uen et al., 2005). The process of HRservice quality links those factors that affect perceived HR service quality to the consequences of perceived HR service quality, such as interaction and co-operation (Uen et al., 2012, 2005). Input of HR service represents the structure, practices, technology, resources and equipment to support services (Uen et al, 2012). The literature indicates that well-designed HRM practices and a wellestablished structure are crucial for enhancing HR service quality (Meijerink, Bondarouk and Lepak, 2016; Lin, 2012; Marler and Parry, 2015; Uen et al., 2012).

Based on these theoretical underpinnings and empirical results, we argue that HRM service quality mediates the link between e-HRM and labour productivity. This study takes the first step 
to test this relationship by examining the impact of e-HRM and labour productivity through the mediating role of HR service quality. Specifically, we hypothesize that

H4: HRM service quality mediates the relationship between e-HRM and managers' perceptions of labour productivity.

\section{Pakistan's Business Context}

Context matters in e-HRM research because the adoption of e-HRM practices varies from sector to sector and country to country (Bondarouk, Schilling, \& Ruël, 2016; Obeidat, 2016), creating the need to study, as this paper does, particular sectors in specific countries. In addition, emphasizing the need for studies to examine the links between e-HRM and productivity in emerging economies, Bondarouk et al. (2016) have noted that most empirical evidence on the relationship between e-HRM and strategic organizational outcomes is from developed economies. Existing research, therefore, highlights 1) the importance of country-specific values as these influence the relationship between e-HRM and organizational outcomes (Ahmad and Allen, 2015; Peretz and Parry, 2016) and 2) that e-HRM is not automatically suitable for developing economies.

Pakistan is a South Asian lower-middle income country with a population of 195.5 million (Economic Survey of Pakistan, 2016). There are 25 commercial banks listed on Pakistan's stock exchange. During the last few years, banks have expanded their branch network and some new commercial banks have emerged (SBP, 2010), increasing competition among them and pushing them to rely on their internal resources, such as human resources, for their survival and growth 
(Ahmed et al., 2010; Irfan et al., 2009). Consequently, banks have focused on HRM systems to create value and to compete in the market, leading them to adopt technological innovations, such as e-HRM, to improve organizational performance (Qureshi, Zafar and Khan, 2008). Many managers in Pakistan view policies that emerge in the US as superior to their own (Khilji, 2002), potentially reinforcing the shift towards e-HRM. Although the business environment is unpredictable in many emerging economies (Bondarouk, Schilling, \& Ruël, 2016), the situation in the banking sector is Pakistan is likely to be more stable, facilitating the adoption of e-HRM systems and their use by employees. However, as yet, no studies exist that examine the relationship between e-HRM and labour productivity; this limits our understanding of how appropriate it is for Pakistani firms to emulate some of the HR practices of their US counterparts.

As research on Mexican firms has shown, cultural norms influence how employees respond to eHRM systems (Olivas-Lujan et al., 2007). It is, therefore, unclear if the new e-HRM policies will have the desired effect in Pakistani banks. Unlike many developed economies, Pakistan is characterized by high uncertainty avoidance, power distance and hierarchical power (Hofstede, 2017). As a result, employees may be unwilling to carry out HR tasks that, previously, employees with a lower status may have carried out, limiting non-HR employees' perception of HR service quality and reducing any potential productivity gains.

\section{Research Design and Methods}

\section{Data}

There are no secondary data sources on e-HRM within workplaces in Pakistan. We, therefore, adopted a multistage sampling of the 25 commercial banks in Pakistan, as it is more suitable for 
a large scale enquiry covering a comparatively wide geographical area. In the first stage, we contacted via telephone the HR directors of all the 25 banks to see if they used any e-HRM practices or a system to manage their HR function. We selected only those banks that have had an e-HRM system functioning for at least two years.

We then sent a structured self-administered questionnaire to 11 banks in Islamabad, Rawalpindi, Peshawar, Lahore and Karachi, where, collectively, most commercial activity in Pakistan is concentrated (Ahmad and Allen, 2015). The banks have 1024 branches in the targeted cities. Using a random sampling approach, we invited 516 branches to participate in the research. One questionnaire per branch was sent out. To decrease the risk of common method variance, we used different sources for the explanatory and outcome variables (Chang, van Witteloostuijn, \& Eden, 2010). We asked the line managers to complete the section of the survey on e-HRM and the branch manager to answer the questions on branch performance. Overall, we received a response from 323 branches of the surveyed branches (62\% response rate).

The role of line managers as agents to implement HRM practices is fundamental to understanding how employees interpret and respond to e-HRM value creation proposition (Alfes et al., 2013). In addition, previous studies have illustrated that line managers play an important role in the HRM-performance relationship (Hartog et al., 2013; Purcell \& Hutchinson, 2007). As Purcell and Hutchinson (2007, p. 6) noted, line managers' behaviour and point of view 'has to be included in any causal chain seeking to explain and measure the relationship between HRM and organizational performance.' Although many e-HRM studies use HR managers only to explore value creation proposition, key information about how HRM policies operates lies with line 
managers (Keenoy, 1999; Khilji et al., 2007). Importantly, line managers as well as HRM professionals deliver HR activities (Parry, 2011; Obeidat, 2016; Stroehmeier 2007), making line managers' knowledgeable about HRM policies and employees' views of them. As the implementation of HRM policies is likely to vary between establishments (Tüselmann et al., 2007), this study focuses on individual branches and the line and branch managers within them.

\section{Scale development and Measures}

Using a seven-point Likert scale, we asked respondents to indicate the use of particular e-HRM practices. The scale ranged from 1, habitually used; 2, quiet frequently used; 3, slightly frequently used; 4, neither frequently nor infrequently used; 5, slightly infrequently used; 6, infrequently used; to 7, not used. Drawing on previous e-HRM research (Bissola and Imperatori, 2013; Cranet survey, 2009; Parry, 2011; Parry and Tyson, 2011), we focus on nine e-HRM practices: performance management, performance appraisal, benefit management, recruitment, selection, training and development, grievance management, talent management and knowledge management. Table 1 provides the details of these items. Building on arguments from the eHRM literature, we create a bundle of e-HRM practices rather than testing for the individual effects of each practice (Bissola \& Imperatori, 2013; Parry, 2011).

We used the perceived quality of the HR service and labour productivity as endogenous latent variables. Adapting Bondarouk et al.'s (2017) and Wahyudi and Park's (2014) HR service quality scale, we measured the perceived quality of the HR service using six items (see Table 1). For the reasons noted above, we used managers' perceptions of employee productivity when analysing the relationship between e-HRM and productivity. In addition, other studies have used 
perceived labour productivity on the basis that it is a valid and reliable measure (Ahmad and Allen, 2015; Bryson et al., 2006; Goodhue and Thompson, 1995; WERS, 2004).

We used five measures of perceived labour productivity on seven-point Likert scales adapted from previous studies (Goodhue and Thompson, 1995; Jain and Kanungo, 2005; WERS, 2004; Kraemer and Danziger, 1990). For example the measure 'We believe that the productivity of our employees is better than that of our competitors' is taken from WERS (2004). Absenteeism and presenteeism were also used to measure perceived labour productivity (Koopman et al. 2002). The measure 'Since the implementation of e-HRM, the average absentee rate is lower' is used to evaluate absenteeism as an element of productivity. The quality and quantity of work (QQ) scale, task productivity and innovation task were also used to measure labour productivity. The item 'eHRM makes employees' jobs much easier' that was adapted from $\mathrm{Wu}$ and $\mathrm{Wu}(2005)$ and is used to assess the task productivity dimension of the perceived labour productivity (Goodhue and Thompson, 1995; Jain and Kanungo, 2005). Our measure of perceived labour productivity is, therefore, based on items, which are drawn from the literature, that cover absenteeism, presenteeism, quality and quantity work, task productivity and innovation productivity; a panel of experts (two academics and three industry experts) also validated our measures.

We used a common technique (Hair et al., 2006), exploratory factor analysis, to validate our scales. All the items were significantly loaded on their respective construct. All factor loadings are greater than the threshold value of 0.70 , indicating that the scale is reliable and valid as shown in Table 2 . The discriminant validity, convergent validity and composite reliability also illustrated that the measure used for labour productivity has statistical validity and reliability. 
The theoretical discussion and statistical validation suggested that the measures used are quite relevant. As previous research has found that organizational size and age are predictors of labour productivity (Parry, 2011), we used these as control variables.

Table 1 to be inserted here

\section{Common Method Variance}

As noted above, we used different sources for the explanatory and outcome variables to reduce the risk of CMV. Various techniques exist to check for CMV (Podsakoff et al., 2003). The one most commonly used in HRM and IS research is the Harman single factor test (Bondarouk et al., 2017; Parry, 2011; Prieto-Pastor \& Martin-Perez, 2015; 2013). We checked for CMV by using the Harman test as well as exploratory factor analysis. The test and analysis demonstrate that no single factor accounted for substantial variance; therefore, CMV cannot be assumed for the study.

\section{Analytical Strategy: Structure Equation Modelling}

Using SMART PLS, we estimated our conceptual model through PLS-SEM, which is commonly used in business research for exploratory studies (Hair et al., 2016) and is a powerful technique for assessing causal relationships. Covariance-based SEM assumes that data should be perfectly normalized; PLS-SEM does not. Predictive generalization is an added characteristic of PLS-SEM (Chen, 1998; Henseler, 2009; Hair et al., 2016). Following Anderson and Gerbing (1988), we tested our model by applying a two-step process proposed. First, using confirmatory factor analysis to test the reliability and validity of the constructs, we assessed the measurement model. 
Second, we used the structural model to assess the relationship between exogenous and endogenous variables.

\section{Evaluating the Measurement Model}

Following Hair et al.'s (2016) recommendations, we evaluated our measurement model using factor analysis, internal consistency reliability, convergent and discriminant validity. We analysed all factors to ensure indicator reliability. Hair et al. (2016) proposed that any item with a factor loading less than 0.40 be deleted. An item with a factor loading between 0.40 and 0.70 can be removed from analyses when its removal increases average variance extracted (AVE); otherwise it should be retained All items with loadings greater than 0.70 should be included in the analysis (Hair et al., 2016). In our case, all factors were significant and no factor was below the cut-off value of 0.40 , confirming the reliability of our indicator shown in Table 2.

Table 2 to be inserted here

Once we had removed items based on the above criteria, we assessed internal consistency through composite reliability and Cronbach alpha (Hair et al., 2016; Vinzi et al., 2010). Composite reliability and Cronbach alpha values are greater than the threshold value of 0.7 , indicating that all constructs of the study are internally consistent as shown in Table 3 . Convergent validity indicates that a block of indicators explains the same theoretical concept. In this study we assessed convergent validity through AVE, the value of which was greater than 0.50 , indicating that convergent validity is tenable, as shown in Table 3 . 
Table 3 to be inserted here

Discriminant validity complements convergent validity and assesses if theoretically distinct constructs are different in reality (Forrel \& Larcker, 1981). We used Fornell-Larcker criterion with cross loading to evaluate discriminant validity; the results indicated no discriminant validity issues.

\section{Evaluating Structural Model and Hypothesis Testing}

Once we confirmed the validity of our measurement model, we evaluated the structural model (Hair et al., 2012; Henseler, Hubona and Ray, 2016), using the coefficient of determination $\left(R^{2}\right)$ for each endogenous variable that relates to variation in a dependent latent variable and that is accounted for by an independent latent variable (Tabachnick and Fidell, 2013; Hair et al., 2010) and significance of path coefficient. There are two endogenous latent variables in this study. Table 4 provides the coefficient of determination for our model. $R^{2}$ values indicate that the study's predictors account for 47 per cent of the variance in labour productivity. The $R^{2}$ for HR service quality is 0.71 , indicating that e-HRM accounted for approximately 70 per cent of the variance in HRM service quality. We estimated Stone-Geisser's $\mathrm{Q}^{2}$ for predictive relevance of the inner model (Hair et al., 2016). The $\mathrm{Q}^{2}$ values for the quality of the HR service $\left(\mathrm{Q}^{2}=0.601\right)$ and labour productivity $\left(\mathrm{Q}^{2}=0.503\right)$ are well above the cut-off value of zero, suggesting that eHRM has enough predictive relevance for HRM service quality and labour productivity.

Table 4 to be inserted here 
We estimated the coefficients and statistical significance using a bootstrapping technique to empirically validate the proposed theoretical association between constructs. Table 5 presents direct, positive and significant relationship between the use of e-HRM practices and labour productivity $(\mathrm{t}=4.570, \beta=0.284)$. Therefore, $\mathrm{H} 1$ is supported. The use of e-HRM practices $(\mathrm{t}=11.192 ; \beta=0.563)$ has a positive and significant relationship with HR service quality; therefore, $\mathrm{H} 2$ is accepted. Table 7 also shows that HR service quality has a statistically significant, direct and positive impact on labour productivity $(\mathrm{t}=8.205 ; \beta=0.427)$; therefore, H3 is supported.

Table 5 to be inserted here

\section{Mediation Analysis}

We use various steps to analyse the mediating effect of HRM service quality through a bootstrapping procedure as recommended by Hair et al., (2016). First, the exogenous variables have to influence the endogenous variable directly. Second, the indirect path should be statistically significant; this is essential requirement for mediation analysis (Hair et al., 2016). The final step involves estimating the size of the indirect effect. This could be accessed through the 'value accounted for' (VAF) measure that indicates the ratio of indirect effect to total effect. The direct relationship (without mediators) between e-HRM strength and labour productivity is significant; therefore, it fulfils the first condition of mediation. Although this is not a strict condition for mediation, it is important when interpreting the mediating effect (Hair et al (2016). Table 6 indicates the indirect effect between e-HRM practices and labour productivity are statistically significant satisfying the central condition of mediation. Supporting H4, HR service 
quality fully mediate the relationship between e-HRM practices and labour productivity as VAF is $95 \%$ of total effect.

Table 6 to be inserted here

\section{Discussion and Conclusion}

Our study responds to recent calls 1) to examine the effect of e-HRM on labour productivity (Obeidat, 2016; Marler and Fisher, 2013) and 2) to extend HRM research to non-Western institutional and cultural contexts (Budhwar and Debra, 2009; Panayotopoulou, Galanaki and Papalexandris, 2010). We analysed whether e-HRM influences labour productivity in the context of commercial banking in Pakistan. A key reason for introducing e-HRM is to improve employee productivity (CedarCrestone, 2008; Marler and Fisher, 2013; Obeidat, 2016; Strohmeier, 2007). We found that e-HRM can improve labour productivity. The results indicate that e-HRM practices have a significant, positive direct impact $\left(\mathrm{R}^{2}=.438 ; \mathrm{Q}^{2}=.601\right)$ on managers' perceptions of labour productivity. The finding is consistent with CedarCrestone (2013) that also argued that e-HRM significantly improves labour productivity. These findings suggest that the greater use of e-HRM practices directly leads to an improvement in labour productivity.

Consistent with previous research, our study confirms a significant and positive association between e-HRM and HRM service quality (Bondarouk and Ruël, 2009; Bondarouk et al., 2017; Strohmeier, 2007; Wahyudi and Park, 2014). This is an important finding as employees' acceptance of new technologies, such as e-HRM systems, cannot be assumed, especially in countries such as Pakistan that have high power distance. Many studies have focused on the 
introduction of e-HRM from the employer's perspective to assess the links between e-HRM and the efficiency of the HRM function (Parry, 2011). We include managers who are not part of the HRM function in our research. Their perspective is important, as e-HRM may externalize some of the activities associated with HRM transactions on to non-HRM employees, potentially reducing their productivity. We found that the e-HRM influences labour productivity when internal customers have a positive behaviour towards e-HRM. In this context, HRM service quality (HSQ) is key intervening variable between e-HRM and labour productivity. The value of VAF measure demonstrated that HSQ mediates the relationship between e-HRM and labour productivity.

Extending previous empirical work, our study suggests that HRM service quality plays a central role in explaining the links between e-HRM and labour productivity. In line with Uen et al.'s (2005, 2012) theoretical work, our results indicate that perceived HR service quality fully mediates the relationship between e-HRM and labour productivity. This suggests that it is not the impact of e-HRM directly on productivity that is important, but that it is the links between eHRM and perceived HR service quality that are associated with increases in productivity. It cannot, therefore, be argued that simply introducing e-HRM is sufficient to improve managers' perceptions of labour productivity. E-HRM is not just the automation or 'self-servicization' of HRM activities. Rather, our results that rely on managers' assessments of the impact of e-HRM demonstrate e-HRM can help to improve labour productivity when it provides a high-quality service to employees that enables workers to perform $\mathrm{HR}$ and non-HR activities better (Bondarouk et al., 2017; Ruel and Kaap, 2012). 


\section{Practical implications}

Implementing e-HRM is not always easy for firms (Bondarouk et al., 2017). Practitioners often use e-HRM to improve their ability to recruit and manage human capital (Marler and Fisher, 2016). However, without clearly understanding the e-HRM value proposition, practitioners may incorrectly estimate the overall impact of e-HRM on the organization or may downplay its wider impact on employees. This study has shown that e-HRM and HR service quality can have a significant influence on improvement of perceived labour productivity. Hence, HR directors and managers should ensure that they design e-HRM system to support organization workflow. In particular, managers should focus on the impact of e-HRM on HR service quality holistically, as this is the 'route' via which e-HRM can improve labour productivity. Put differently, this study argues that the introduction of e-HRM alone is insufficient to improve organizational outcomes; the firm will benefit only if e-HRM helps employees to perform a range of their tasks quicker or more easily.

\section{Theoretical implications}

This study's theoretical contributions are fourfold. First, this study enriches the HRM literature by providing important predictors for labour productivity. Obeidat (2016) suggested that relationship between e-HRM and labour productivity is still a grey area. Thus, we have filled an important gap in the literature by examining the impact of e-HRM on managers' perceptions of labour productivity. Our results indicate that e-HRM is an important predictor for improving labour productivity, a factor to help companies achieve sustainable competitive advantage (Paauwe, 2009). 
Second, we found that the perceived quality of HR services fully mediates the relationship between e-HRM and managers' perceptions of labour productivity. This result suggests that eHRM can help employees to be more effective and efficient when e-HRM frees up non-HRM employees to focus on their core activities or by reducing the errors associated with HRM activities. Thus, our study extends the existing e-HRM models and identifies HR service quality acts as a contingent variable between e-HRM and organizational outcomes.

Third, our study demonstrates that models of e-HRM should not only focus on more proximal outcomes, such as the HRM function's productivity, but should also examine more distal outcomes, such as workplace labour productivity. Frequently, e-HRM is introduced not just to improve the deployment of HRM personnel and resources, but to impact on the organization more widely. Theoretical models should, therefore, capture that multiplicity of intended outcomes.

Finally, the majority of empirical evidence on e-HRM comes from developed countries (Bondarouk et al., 2016). Less research has focused on the adoption of e-HRM in developing and South Asian countries. This study provides empirical evidence regarding value creation proposition for commercial bank of Pakistan. Cultural norms matter in e-HRM research because these will influence how e-HRM practices are enacted (Olivas-Lujan et al., 2007). We have shown that within the context of commercial banks in Pakistan, a sector that is important to the national economy and that has witnessed the introduction of e-HRM systems, e-HRM is associated with perceived productivity advantages in companies. Though more studies are 
required to explore the influence of e-HRM on performance of workforce and should include other aspects, such as turnover and employee commitment, this study has provided a useful starting point for measuring the impact of e-HRM on labour productivity.

\section{References}

Ahmad, M. and Allen, M.M.C. (2015). High Performance HRM and Establishment Performance in Pakistan: an Empirical Analysis. Employee Relations, 37(5), 506-524.

Alfes, K., Truss, C., Soane, E.C., Rees, C., \& Gatenby, M. (2013). The relationship between line manager behavior, perceived HRM practices, and individual performance: Examining the mediating role of engagement. Human Resource Management, 52(6), 839-859.

Anderson, J.C. and Gerbing, D.W. (1988). Structural equation modeling in practice: A review and recommended two-step approach. Psychological Bulletin, 103(3), 411-423.

Aryee, S., Walumbwa, F.O., Seidu, E.YM., \& Otaye, L.E. (2013). Developing and leveraging human capital resource to promote service quality: Testing a theory of performance. Journal of Management, 42(2), 1-20.

Bissola, R. and B. Imperatori (2013). Facing e-HRM: the consequences on employee attitude towards the organisation and the HR department in Italian SMEs. European Journal of International Management 7(4), 450-468.

Bissola, R. and B. Imperatori (2013). Facing e-HRM: the consequences on employee attitude towards the organisation and the HR department in Italian SMEs. European Journal of International Management, 7(40), 450-468.

Bissola, R., \& Imperatori, B. (2014). The unexpected side of relational e-HRM: Developing trust in the HR department. Employee Relations, 36(4), 376-397. 
Bondarouk, T. and Ruël, H. (2013). The strategic value of e-HRM: results from an exploratory study in a governmental organization. International Journal of Human Resource Management, 24(2), 391-414.

Bondarouk, T., Harms, R., \& Lepak, D. 2017. Does e-HRM lead to better HRM service? International Journal of Human Resource Management, 28(9), 1332-1362.

Bondarouk, T.V. and Ruël, H.J.M. (2009). Electronic Human Resource Management: challenges in the digital era. International Journal of Human Resource Management, 20(3), 505514.

Bondarouk, T., Schilling, D., \& Huub, R. (2016). eHRM adoption in emerging economies : The case of subsidiaries of multinational corporations in Indonesia. Canadian Journal of Administrative Sciences, 33(2), 124-137.

Brynjolfsson, E. (1993). The productivity paradox of information technology. Communications of the ACM, 36(12), 67-77.

Brynjolfsson, E., \& Hitt, L.M. (2003). Computing productivity: Firm-level evidence. Review of Economics and Statistics, 85(4), 793-808.

Bryson, A., Charlwood, A., \& Forth, J. (2006). Worker voice, managerial response and labour productivity: An empirical investigation. Industrial Relations Journal, 37(5), 438-455.

Budhwar, P.S. and Debrah, Y.A. (2009). Human resource management in developing countries, in Wilkinson, A., Bacon, N., Redman, T. and Snell, S. (Eds), The Sage Handbook of Human Resource Management, Sage, London, 393-406.

Calabrese, A. (2012). Service productivity and service quality: A necessary trade-off? International Journal of Production Economics, 135(2), 800-812. 
CedarCrestone (2006). Workforce Technologies and Service Delivery Approaches. Survey (9th Annual edition). Albany, New York.

CedarCrestone (2008). Cedar Crestone 2008-2009 HR Systems Survey (11th Annual Edition)'. Albany, New York.

CedarCrestone (2009). CedarCrestone 2009-2010 HR Systems Survey: HR Technologies, Deployment Approaches, Value, and Metrics (12th Annual Edition). Albany, New York. CedarCrestone (2013). CedarCrestone 2013-2014 HR Systems Survey: HR Technologies, Deployment Approaches, Value, and Metrics (15th Annual Edition). Albany, New York. Chang, E. (2005). Employees' overall perception of HRM effectiveness. Human Relations, $58(4), 523-544$.

Chang, S.-J., van Witteloostuijn, A., \& Eden, L. (2010). Common method variance in international business research. Journal of International Business Studies, 41(2), 178184.

Datta, D.K., Guthrie, J.P., \& Wright, P.M. (2005). Human Resource Management and Labor Productivity: Does Industry Matter? Academy of Management Journal, 48(1), 135-145.

Delery, J.E., \& Shaw, J.D. (2001). The strategic management of people in work organizations: Review, synthesis, and extension. In Research in Personnel and Human Resources Management (165-197). Emerald Group Publishing Limited.

DeLone, W.H., \& McLean, E.R. (2003). The DeLone and McLean model of information systems success: a ten-year update. Journal of Management Information Systems, 19(4), 9-30.

DeLone, W.H., \& McLean, E.R. (1992). Information systems success: The quest for the dependent variable. Information Systems Research, 3(1), 60-95. 
Drucker, P.F. (1999). Knowledge worker productivity: The biggest challenge. California Management Review, 41(2), 79-94.

Fornell, C., Larcker, D.F., 1981. Evaluating structural equation models with unobservable variables and measurement error. Journal of Marketing Research, 18(1), 39-50.

Gorla, N., Somers, T.M., \& Wong, B. (2010). Organizational impact of system quality, information quality, and service quality. The Journal of Strategic Information Systems, 19(3), 207-228.

Goodhue, D.L., \& Thompson, R.L. (1995). Task-technology fit and individual performance. MIS Quarterly, 19(2), 213-236.

Hair, J.F., Black, W. C., Babin, B.J., \& Anderson, R.E.(2010). Multivariate Data Analysis. Englewood Cliffs: Prentice Hall.

Hair, J.F., Sarstedt, M., Ringle, C.M., \& Mena, J.A. (2012). An assessment of the use of partial least squares structural equation modeling in marketing research. Journal of the Academy of Marketing Science, 40(3), 414-433.

Hair, J.F., Hult, G.T.M., Ringle, C., \& Sarstedt, M. (2016). A primer on partial least squares structural equation modeling (PLS-SEM). Sage Publications

Hair, J.F., Anderson, R.E., Tatham, R.L., \& William, C. Black (2006), Multivariate Data Analysis. International Edition, New Jersey: Prentice Hall.

Hartog, D.N., Boon, C., Verburg, R.M., \& Croon, M.A. (2013). HRM, Communication, satisfaction, and perceived performance: A cross-level test. Journal of Management, 39(6), $1637-1665$

Henseler, J., Hubona, G., \& Ray, P. (2016). Using PLS path modeling in new technology research: updated guidelines. Industrial Management \& Data Systems, 116(1), 2-20. 
Holm, A.B. (2014). Institutional context and e-recruitment practices of Danish organizations. Employee Relations, 36(4), 432-455.

Hofstede, G. (2016), Strategy, culture, change, The Hofstede Center, available at: http://geerthofstede.com/pakistan.html (accessed June 15, 2016).

Jain, V., \& Kanungo, S. (2005). Beyond perceptions and usage: impact of nature of information systems use on information system-enabled productivity. International Journal of HumanComputer Interaction, 19(1), 113-136

Johnson, R.D., Lukaszewski, K.M., \& Stone, D.L. (2016). The evolution of the field of human resource information systems: Co-evolution of technology and HR processes. Communications of the Association for Information Systems, 38(28), 533-553.

Khilji, S.E. (2001). Human resource management in Pakistan. In P. Budhwar and D. Yaw (Eds.), Human Resource Management in Developing Countries. London: Routledge

Khilji, E. (2002). Modes of convergence and divergence: An integrative view of multinational practices in Pakistan. International Journal of Human Resource Management, 13(2), 232253

Khilji, S.E., \& Wang, X. (2007). New evidence in an old debate: Investigating the relationship between HR satisfaction and turnover. International Business Review, 16(3), 377-395.

Koopman, C., Pelletier, K.R., Murray, J.F., Sharda, C.E., Berger, M.L., Turpin, R S. \& Bendel, T. (2002). Stanford presenteeism scale: health status and employee productivity. Journal of Occupational and Environmental Medicine, 44(1), 14-20.

Marler, J.H., \& Fisher, S.L. (2013). Human Resource Management Review An evidence-based review of e-HRM and strategic human resource management. Human Resource Management Review, 23(1), 18-36. 
Meijerink, J.G., Bondarouk, T., \& Lepak, D.P. (2016). Employees as active consumers of HRM: Linking employees' HRM competences with their perceptions of HRM service value. Human Resource Management, 55(2), 219-240.

Obeidat, S.M. (2016). The link between e-HRM use and HRM effectiveness: an empirical study. Personnel Review, 45(6), 1281-1301.

Olivas-Lujan, M.R., Ramirez, J., \& Zapata-Cantu, L. (2007). e-HRM in Mexico: adapting innovations for global competitiveness. International Journal of Manpower, 28(5), 418434.

Paauwe, J., \& Boselie, P. (2005). HRM and performance: what next?. Human Resource Management Journal, 15(4), 68-83.

Panayotopoulou, L., Galanaki, E., \& Papalexandris, N. (2010). Adoption of electronic systems in HRM: Is national background of the firm relevant?. New Technology, Work and Employment, 25(3), 253-269.

Parasuraman, A., Berry, L.L., and Zeithaml, V.A. (1988), SERVQUAL: A Multiple-Item Scale for Measuring Consumer Perceptions of Service Quality. Journal of Retailing, 64, 12-40.

Panos, S., \& Bellou, V. (2016). Maximizing e-HRM outcomes: a moderated mediation path. Management Decision, 54(5), 1088-1109.

Parry, E. (2011). An examination of e-HRM as a means to increase the value of the HR function. International Journal of Human Resource Management, 22(5), 1146-1162.

Parry, E., \& Tyson, S. (2011). Desired goals and actual outcomes of e-HRM. Human Resource Management Journal, 21(3), 335-354.

Parry, E., \& Strohmeier, S. (2014). HRM in the digital age: digital changes and challenges of the HR profession. Employee Relations, 36(4), Editorial. 
Podsakoff, P.M., MacKenzie, S.B., Lee, J.-Y. and Podsakoff, N.P. (2003). Common method biases in behavioral research: A critical review of the literature and recommended remedies. Journal of Applied Psychology, 88(5), 879-903.

Peretz, H., \& Parry, E. (2016). Impact of National Culture on the Use and Outcomes of E-HRM. In Academy of Management Proceedings, 2016(1), 10891.

Pitt, L.F., Watson, R.T., \& Kavan, C.B. 1995. Service quality: A measure of information systems effectiveness. MIS Quarterly, 19(2), 173-187.

Polák, P. 2017. The productivity paradox: A meta-analysis. Information Economics and Policy, $38,38-54$.

Prieto-Pastor, I., \& Martin-Perez, V. (2015). Does HRM generate ambidextrous employees for ambidextrous learning? The moderating role of management support. International Journal of Human Resource Management, 26(5), 589-615.

Purcell, J., \& Hutchinson, S. (2007). Front-line managers as agents in the HRM- performance causal chain: theory, analysis and evidence. Human Resource Management Journal, 17(1), $3-20$.

Ruël, H., \& van der Kaap, H. (2012). E-HRM usage and value creation. Does a facilitating context matter? German Journal of Human Resource Management, 26(3), 260-281

Shrivastava, S. and J.B. Shaw, 2003. Liberating HR through technology, Human Resource Management, 42(3), 201-222.

Snell, S.A., Stuebner, D., \& Lepak, D.P. (2002). Virtual HR departments: Getting out of the middle, 81-101, in R. L. Henneman \& D. B. Greenberger (Eds). Human resource management in virtual organizations, Greenwich: Information Age Publishing.

Sabir, S., Abrar, M., Bashir, M., Baig, S.A., \& Kamran, R. (2015). E-hrm impact towards 
company's value creation: evidence from banking sector of Pakistan. International Journal of Information Management, 7(2), 123-143.

Schalk, R., Timmerman, V., \& Heuvel, S. Van Den. (2013). How strategic considerations in fluence decision making on e-HRM applications. Human Resource Management Review, 23(1), 84-92.

Stone, D.L., \& Dulebohn, J.H. (2013). Emerging issues in theory and research on electronic human resource management (eHRM ). Human Resource Management Review, 23(1), 1-5.

Strohmeier, S. (2007). Research in e-HRM: Review and implications. Human Resource Management Review, 17(1), 19-37.

Strohmeier, S., \& Kabst, R. (2014). Configurations of e-HRM: an empirical exploration. Employee Relations, 36(4), 333-353.

Tam, C., \& Oliveira, T. (2016). Understanding the impact of m-banking on individual performance: DeLone \& McLean and TTF perspective. Computers in Human Behavior, 61, $233-244$.

Tabachnick, B.G. and Fidell, L.S. (2013) Using Multivariate Statistics, (6th ed), New Jersey: Pearson Education, Inc.

Tüselmann, H.-J., McDonald, F., Heise, A., Allen, M.M.C. and Voronkova, S. (2007), Employee Relations in Foreign-Owned Subsidiaries: German Multinational Companies in the UK, Palgrave Macmillan, Basingstoke.

Uen, J., Wang, B., \& Chen, W. (2005). Internal service quality factors of human resource department and their relationships with organizational performance: Top and middle managers' viewpoints. Taiwan Journal of Human Resource Management, 5(2), 39-66.

Uen, J.F., Ahlstrom, D., Chen, S.Y., \& Tseng, P.W. (2012). Increasing HR's strategic 
participation: The effect of HR service quality and contribution expectations. Human Resource Management, 51(1), 3-23.

Wahyudi, E., \& Park, S. (2014). Unveiling the Value Creation Process of Electronic Human Resource Management: An Indonesian Case. Public Personnel Management, 43(1), 83-117. Wu, I L., \& Wu, K.W. (2005). A hybrid technology acceptance approach for exploring e-CRM adoption in organizations. Behaviour \& Information Technology, 24(4), 303-316.

Zheng, C., \& Lamond, D. (2010). Organisational determinants of employee turnover for multinational companies in Asia. Asia Pacific Journal of Management, 27, 423-443 
Table 1 Construct and Items

\begin{tabular}{|c|c|}
\hline Construction & Items \\
\hline \multirow[t]{9}{*}{ Use of e-HRM practices } & Our organization uses e-HRM for managing employee benefits (EHRMP1) \\
\hline & We use e-HRM for recruitment $\&$ selection processes. (EHRMP2) \\
\hline & $\begin{array}{l}\text { We use e-HRM for forma } \\
1 \text { grievances \& complaints (EHRMP3) }\end{array}$ \\
\hline & We use e-HRM for work scheduling (EHRMP4) \\
\hline & we use e-HRM for online testing \& learning (EHRMP5) \\
\hline & e-HRM is used to appraise branch employees in our organization (EHRMP6) \\
\hline & e-HRM is used to review the performance of the branch employee (EHRMP7) \\
\hline & e-HRM is used for internal hiring \& transfer (EHRMP8) \\
\hline & In my organization, e-HRM is used for talent management (EHRMP9) \\
\hline \multirow[t]{6}{*}{ Quality HR services } & $\begin{array}{l}\text { e-HRM provides quality HR services to its internal customers (managers, } \\
\text { employees) (QHRS1) }\end{array}$ \\
\hline & Our e-HRM system guarantees errorless administration (QHRS2) \\
\hline & $\begin{array}{l}\text { Ever since the introduction of e-HRM, HR services have been performed } \\
\text { correctly and in appropriate way (QHRS3) }\end{array}$ \\
\hline & E-HRM improves the quality of HR services (QHRS4) \\
\hline & E-HRM enables managers to accomplish tasks quickly (QHRS5) \\
\hline & $\begin{array}{l}\text { HR services have been streamlined and standardized in our organization } \\
\text { (QHRS6) }\end{array}$ \\
\hline \multirow[t]{5}{*}{ Labour Productivity } & $\begin{array}{l}\text { We believe that the productivity of our employee is better than that of our } \\
\text { competitors (LP1) }\end{array}$ \\
\hline & Since the implementation of e-HRM average absentee rate are reduced (LP2) \\
\hline & Using e-HRM, our average effective hour loss is lower (LP3) \\
\hline & e-HRM makes our job much easier (LP4) \\
\hline & $\begin{array}{l}\text { e-HRM has increased the focus of managers and employees on their core duties } \\
\text { (LP5) }\end{array}$ \\
\hline
\end{tabular}


Table 2 Factor Analysis

\begin{tabular}{|l|r|r|r|r|}
\hline & EHRM use & LP & \multicolumn{1}{c|}{ QHRS } & \multicolumn{1}{c|}{ t-value } \\
\hline EHRMP2 & 0.652034 & & & 14.29101 \\
\hline EHRMP3 & 0.664004 & & & 19.17053 \\
\hline EHRMP5 & 0.599436 & & & 13.67823 \\
\hline EHRMP6 & 0.789675 & & & 30.86524 \\
\hline EHRMP7 & 0.85301 & & & 42.80017 \\
\hline EHRMP8 & 0.670388 & & & 12.97555 \\
\hline EHRMP9 & 0.704512 & & & 17.80193 \\
\hline LP1 & & 0.76003 & & 23.48987 \\
\hline LP2 & & 0.842118 & & 44.68202 \\
\hline LP3 & & 0.896798 & & 63.96608 \\
\hline LP4 & & 0.840069 & & 31.34868 \\
\hline LP5 & & 0.83508 & & 32.75188 \\
\hline QHRS1 & & 0.742488 & 20.45931 \\
\hline QHRS 2 & & & 0.766841 & 24.9185 \\
\hline QHRS 3 & & & 0.784119 & 27.05697 \\
\hline QHRS 4 & & & 0.802918 & 23.63137 \\
\hline QHRS 5 & & & 0.82807 & 32.51654 \\
\hline QHRS 6 & & & & 28.55535 \\
\hline
\end{tabular}

Table 3 Construct Reliability and Validity

\begin{tabular}{|l|c|r|r|}
\hline Construct & Composite Reliability & Cronbach alpha & AVE \\
\hline e-HRM use & 0.874962 & 0.837336 & 0.503192 \\
\hline HR service quality & 0.907356 & 0.877421 & 0.620393 \\
\hline Labour productivity & 0.920447 & 0.891741 & 0.698828 \\
\hline Org_size & 1.0000 & 1.0000 & 1.000 \\
\hline Org_age & 1.0000 & 1.0000 & 1.000 \\
\hline
\end{tabular}


Table 4 Predictor Relevancy of the Model

\begin{tabular}{|c|c|c|c|}
\hline Predictor Variable & Endogenous variable & R2 & $\mathrm{Q}^{2}$ \\
\hline EHRMP & QHRS & .317 & .503 \\
\hline $\begin{array}{c}\text { EHRMP, QHRS, org_size, } \\
\text { org_age }\end{array}$ & LP & .438 & .601 \\
\hline
\end{tabular}

Note: E-HRMP=E-HRM practices use; QHRS: HR service quality; LP= Labour Productivity

Table 5 Direct-Effect Test

\begin{tabular}{|c|r|r|r|r|}
\hline Hypotheses & \multicolumn{1}{|c|}{ t-value } & \multicolumn{1}{c|}{$\boldsymbol{\beta}$} & $\begin{array}{c}\text { Significant } \\
\text { Hypothesized } \\
\text { Relation }\end{array}$ & \multicolumn{1}{|c|}{ Decision } \\
\hline H1 & 4.570 & 0.284 & EHRMP-> LP & Supported \\
\hline H2 & 11.192 & 0.563 & EHRMP-> QHRS & Supported \\
\hline H3 & 8.205 & 0.427 & QHRS-> LP & Supported \\
\hline
\end{tabular}

Table 6 Mediation Test

\begin{tabular}{|c|c|c|c|c|c|c|}
\hline Hypothesis & Indirect relation & t-value & $\begin{array}{l}\text { Indirect effect } \\
\left(a^{*} b\right)\end{array}$ & $\begin{array}{l}\text { Total } \\
\text { effect }\end{array}$ & VAF & Status \\
\hline \multirow[t]{3}{*}{$\mathrm{H} 4$} & EHRMP-> QHRS & 11.192 & $\beta 2=6.301$ & $\beta 1=.658$ & \multirow{3}{*}{0.956} & \multirow{3}{*}{$\begin{array}{c}\text { Full } \\
\text { Mediation }\end{array}$} \\
\hline & & & & & & \\
\hline & QHRS-> LP & 8.208 & & & & \\
\hline
\end{tabular}

